\title{
PEMANFAATAN EKSTRAK BUAH MANGROVE UNTUK MENGHAMBAT PEMBENTUKAN MELANOSIS PADA UDANG VANAME (Litopenaeus vannamei)
}

\author{
Tatty Yuniarti ${ }^{1 \star}$, Yuliati Sipahutar ${ }^{2}$, Husnul Khatimah Ramli ${ }^{2}$, Noor Pitto Sari Nio Lita ${ }^{1}$ \\ ${ }^{1}$ Prodi Penyuluhan Perikanan, Sekolah Tinggi Perikanan, Politeknik Ahli Usaha Perikanan (POLTEK AUP) \\ Jalan AUP, Pasar Minggu, Jakarta Selatan, 12520 Telepon 02178830275 \\ ${ }^{2}$ Prodi Teknologi Pengolahan Hasil Perikanan, Sekolah Tinggi Perikanan, Politeknik Ahli Usaha Perikanan \\ (POLTEK AUP) Jalan AUP, Pasar Minggu, Jakarta Selatan, 12520 Telepon 02178830275
}

${ }^{\star}$ Korespondensi: tatty.yuni@gmail.com

Diterima: 2 Desember 2019/Disetujui: 30 April 2020

Cara sitasi: Yuniarti T, Sipahutar Y, Ramli HK, Lita NPSN. 2020. Pemanfaatan ekstrak buah mangrove untuk menghambat pembentukan melanosis pada udang vaname (Litopenaeus vannamei). Jurnal Pengolahan Hasil Perikanan Indonesia. 23(1): 67-76.

\begin{abstract}
Abstrak
Mangrove diketahui mempunyai kemampuan bioaktif untuk menghambat aktivitas enzim tirosinase. Penelitian bertujuan untuk menentukan konsentrasi ekstrak buah mangrove yang berperan dalam menghambat melanosis udang vaname selama penyimpanan 10 hari pada $0^{\circ} \mathrm{C}$. Buah mangrove yang digunakan adalah Rhizophora mucronata, Rhizophora apiculata dan Avicennia marina. Buah mangrove diekstraksi menggunakan air. Konsentrasi ekstrak yang digunakan adalah $25 \%$ dan $50 \%$. Udang disimpan selama 10 hari pada suhu $0^{\circ} \mathrm{C}$ menggunakan coldbox. Rancangan penelitian menggunakan Rancangan Acak Lengkap Faktorial (RALF). Parameter uji melanosis, organoleptik, warna dianalisis dengan ANOVA, dengan uji lanjut duncan. Parameter organoleptik dianalisis dengan uji non parametrik kruskal wallis, uji lanjut multiple comparison. Hasil penelitian menunjukkan udang yang direndam menggunakan ekstrak mangrove $R$. mucronata $50 \%$ dan $R$. apiculata $50 \%$ kemudian disimpan pada suhu $0^{\circ} \mathrm{C}$ mempunyai nilai melanosis terendah dibandingkan dengan ekstrak mangrove lainnya. Kenampakan organoleptik udang dapat dipertahankan dengan perendaman ekstrak R. mucronata $50 \%$ dan R. apiculata $50 \%$, seluruh ekstrak tidak mempengaruhi bau khas dan tekstur udang vaname. Uji warna menunjukkan $R$. mucronata $25 \%$ mempunyai nilai $L^{*}$ tertinggi yang tidak berbeda nyata dengan $R$ mucronata $50 \%$. Nilai $L^{*}$ udang yang direndam $A$. marina $25 \%$ memiliki tingkat keefektifan terendah dalam mempertahankan nilai $\mathrm{L}^{*}$, seluruh jenis ekstrak, tidak mempengaruhi nilai $\mathrm{a}^{*}$ dan $\mathrm{b}^{*}$ warna udang. Ekstrak buah mangrove $R$. mucronata $50 \%$ dan R.apiculata efektif dalam menghambat melanosis udang.
\end{abstract}

Kata Kunci : A. marina, bintik hitam, R. apiculata, $R$. mucronata, sodium metabisulfit

\section{Application of Mangrove Extract for the Melanosis Inhibition in Whiteleg Shrimp (Litopenaeus vannamei)}

\begin{abstract}
Mangroves are known to have bioactive abilities in order to inhibit the activity of the tyrosinase enzyme. The study was aimed to determine the mangrove fruit extracts that inhibiting whiteleg shrimp melanosis during storage of 10 days at $0^{\circ} \mathrm{C}$. Mangroves applied were Rhizophora mucronata, Rhizophora apiculata and Avicennia marina. Mangrove fruit was extracted using water. The extract concentrations used were $25 \%$ and $50 \%$. Shrimps were stored for 10 days at $0{ }^{\circ} \mathrm{C}$ using a cool box. The research design were factorial completely randomized design (RALF) and analyzed with ANOVA for melanosis, organoleptic, color test parameters, and followed by Duncan's tests. Organoleptic parameters were analyzed by the non-parametric kruskal wallis test with further multiple comparison test. The results showed that shrimp soaked in R. mucronata mangrove extract $50 \%$ and R. apiculata $50 \%$ then stored at $0^{\circ} \mathrm{C}$ had the lowest melanosis value compared to other mangrove extracts. The organoleptic appearance of shrimp can be maintained by soaking of R. mucronata extract 50\% and R. apiculata 50\%, all extracts do not affect the odor characteristic and texture of Vanname shrimp. The color test showed that $R$. mucronata $25 \%$ had the highest $L^{\star}$ value which was not significantly different from $R$ mucronata $50 \%$. $L^{*}$ value of shrimp marinated by A. marina $25 \%$ has the lowest level of effectiveness in maintaining the $L^{*}$ value, all types of extracts, does not affect the value of $a^{*}$ and $b^{*}$ shrimp color. The $50 \%$ concentration of mangrove extract R. mucronata and R.apuculata can inhibit shrimp melanosis.
\end{abstract}

Keywords: A. marina, black spots, R. apiculata, R. mucronata, sodium metabisulfite 


\section{PENDAHULUAN}

Komoditas yang turut membantu peningkatan perekonomian petambak di Indonesia, salah satunya adalah komoditas udang. Jenis udang yang paling banyak dibudidaya adalah udang vaname (Litopenaeus vannamei). Jumlah produksi udang vaname pada tahun 2013 adalah sebanyak 376.189 ton, kemudian meningkat pada tahun 2014 sebanyak 428.905 ton, namun terjadi penurunan pada tahun 2015 menjadi 406.795 ton, dan kembali meningkat pada tahun 2016 sebanyak 476.455 ton (Data Statistik DJPB 2017). Kontribusi nilai ekspor udang vaname beku (white leg shrimps) terhadap total nilai ekspor perikanan tahun 2016 mencapai lebih dari 27 persen (Data International Trade Center 2017). Hasil produksi udang Indonesia diekspor ke Malaysia, Singapura, Amerika Serikat dan lain-lain, dalam bentuk segar dan udang beku (Ashari et al. 2016). Kesegaran udang adalah indikator utama mutu udang. Mutu udang dapat dilihat penampakan fisik udang misalnya warna, tekstur dan bau. Mutu udang dapat menurun akibat penanganan udang yang tidak baik pada rantai distribusi (Imran et al. 2013). Penurunan mutu udang disebabkan oleh faktor-faktor intrinsik dan ektrinsik. Faktor intrinsik tersebut antara lain reaksi autolisis, bakteriologis, dan oksidasi (Morrissey dan Sylvia 2004).

Penurunan mutu udang akibat reaksi oksidasi enzimatis adalah pembentukan melanosis. Cephalothorax udang diketahui mengandung enzim polifenoloksidase yang tinggi. Enzim polifenol oksidase adalah enzim tirosinase yang mengoksidasi asam amino tirosin menjadi quinon kemudian quinon yang bersifat reaktif membentuk makromolekul melanin yang berwarna hitam atau disebut juga dengan istilah black spot. Enzim tersebut aktif pada kondisi optimumnya yaitu $\mathrm{pH} 6$ dan suhu $45^{\circ} \mathrm{C}$ (Giménez et al. 2010).

Pembentukan melanosis merupakan salah satu penyebab pembentukan warna hitam. Udang yang telah terdapat warna hitam menjadi pertimbangan utama konsumen pada penolakan udang segar
(Senapati et al. 2017). Beberapa penelitian diketahui dapat memperlambat pembentukan melanosis pada udang, antara lain perendaman udang dalam campuran larutan genistein 0,1\%, gliserol $2 \%, \mathrm{NaCl} 1 \%$, EDTA $0,05 \%$, asam askorbat $0,5 \%$ dan larutan asam laktat 0,5\% (Rahimabadi et al. 2016). Selain itu melanosis juga dapat dihambat mengunakan ekstrak tanaman yang diketahui mempunyai komponen bioaktif seperti komponen fenolik seperti terpenoid, fenil, piridina, piperidina, pyridinone, hydroxypyridinone, thiosemicarbazone, thiosemicarbazide, azola, tiazolidina, asam kojat, benzaldehida, dan xantat (Zolghadri et al. 2019). Melanosis dapat dihambat oleh ekstrak bawang merah, yang mengandung kuersetin, kaemferol dan sianidin diduga dapat menghambat melanosis (Yuniarti et al. 2018).

Mangrove diketahui mempunyai berbagai komponen fitokimia yang mempunyai kemampuan bioaktif sebagai antioksidan. Kemampuan antioksidan diperlukan untuk menghambat melanosis (Cui et al. 2018). Hasil penelitian A'in et al. (2017), menunjukkan bahwa tepung mangrove memiliki antioksidan tinggi dengan inhibisi $71 \%$. Daun bakau jenis api-api (Avicennia sp.) memiliki kandungan flavonoid yang tinggi sebesar $1,18 \%$ dan nilai $\mathrm{IC}_{50}$ (Inhibitory Concentration 50\%) yang rendah yaitu $36,35 \mathrm{ppm}$, ini menunjukkan bahwa daun api-api memiliki aktivitas antioksidan yang cukup kuat (Handayani 2013). Fitokimia Rhizophora mucronata menunjukkan aktivitas antioksidan tertinggi $(160,42 \mu \mathrm{g} / \mathrm{ml})$ dibandingkan ekstrak metanol $(-117,49 \mu \mathrm{g} / \mathrm{ml})$ dan ekstrak heksana $(327,61$ $\mu \mathrm{g} / \mathrm{mL})$. Ekstrak metanol $R$. mucronata mengandung $1.195 \mu \mathrm{g} / \mathrm{mL}$ flavonoid; 124,44 $\mu \mathrm{g} / \mathrm{mL}$ alkaloid, dan $576,64 \mu \mathrm{g} / \mathrm{mL}$ tannin. Ekstrak etil dan heksana mengandung alkaloid $(44,91 \mu \mathrm{g} / \mathrm{mL}$ dan $41,49 \mu \mathrm{g} / \mathrm{mL})$ dan tanin $(84,84 \mu \mathrm{g} / \mathrm{mL}$ dan $67,30 \mu \mathrm{g} / \mathrm{mL}$ ) (Ridlo et al. 2017). Bakau atau mangrove jenis Rhizophora apiculata diketahui mempunyai kemampuan sebagai inhibitor enzim tirosinase, dan jenis senyawa yang berperan adalah isoflavon (Abdullah 2011). Berdasarkan uraian di atas, penelitian ini bertujuan menentukan konsentrasi ekstrak buah mangrove yang 
berperan dalam menghambat melanosis udang vaname selama penyimpanan 10 hari pada $0^{\circ} \mathrm{C}$.

\section{BAHAN DAN METODE Bahan dan Alat}

Bahan yang digunakan adalah udang vaname, tiga jenis buah mangrove (Rhizophora mucronata, Rhizophora apiculata, Avicennia marina), asam sitrat (Merck) dan sodium metabisulfit komersial. Udang yang digunakan pada penelitian ini diambil dari tambak BAPPL STP Serang dalam keadaan hidup dengan umur \pm 90 hari dan ukuran berkisar 70-80 ekor $/ \mathrm{kg}$. Alat yang digunakan pada penelitian ini antara lain cool box, scoresheet, Chromameter CR-300, sonikator, freezer, kertas saring, glassware.

\section{Metode Penelitian \\ Pembuatan ekstrak buah mangrove}

Ekstraksi buah mangrove mengacu pada Hardoko et al. (2015) dengan modifikasi. Buah mangrove $R$. mucronata, $R$. apiculata, A. marina masing-masing dicuci bersih, kemudian dipotong-potong kecil/dicacah. Buah mangrove selanjutnya direndam dengan asam sitrat $0,5 \%$ selama 10 menit dengan perbandingan 1:3 (b/v). setelah itu dilakukan perendaman buah mangrove dalam akuades dengan perbandingan 1:3 (b/v) selama 3 hari, $\mathrm{pH}$ diukur hingga tidak kurang dari 7. Mangrove selanjutnya dikeringkan selama 2 hari pada suhu ruang. Mangrove kering dibentuk menjadi bubuk/ simplisia. Simplisia tersebut dicampur dengan akuades sebanyak 20x berat simplisia dan disonikasi menggunakan sonikator selama 30 menit agar semakin banyak senyawa yang dapat diekstrak. Filtrat atau ekstrak tersebut dimasukkan ke dalam botol kaca cokelat dan disimpan di dalam freezer hingga digunakan.

\section{Aplikasi ekstrak buah mangrove}

Ekstrak buah mangrove dibuat menjadi masing-masing dua konsentrasi, yaitu 25\% dan 50\% (1:3 dan 1:1) (v/v). Aplikasi ekstrak buah mangrove pada udang segar dilakukan dengan mematikan udang secara cepat terlebih dahulu, yaitu meletakkan udang pada es hingga udang mati. Udang direndam selama
30 menit menggunakan wadah baskom yang ditambahkan larutan ekstrak buah mangrove dingin suhu $5^{\circ} \mathrm{C}$. Ekstrak buah mangrove yang digunakan sebanyak enam perlakuan, yaitu R. mucronata 25\% (v/v) (Muc 25\%), R. mucronata 50\% (v/v) (Muc 50\%), R. apiculata 25\% (v/v) (Api 25\%), R. apiculata $50 \%$ (v/v) (Api 50\%), A. marina 25\% (v/v) (Avi 25\%), A. marina 50\% (v/v) (Avi 50\%). Kontrol adalah udang tanpa penambahan ekstrak dan udang yang ditambahkan sodium metabisulfit 1,25\% (SMS) (Fang et al. 2010). Udang diangkat dari larutan dan disimpan di dalam cool box yang telah berisi es dengan perbandingan 2:1 (suhunya $\pm 0-5^{\circ} \mathrm{C}$ ). Penambahan es dilakukan setiap hari sebanyak satu kali. Pengamatan dilakukan selama 10 hari dengan interval waktu pengamatan 2 hari.

\section{Pengujian melanosis}

Pengujian melanosis dilakukan dengan menggunakan metode Montero et al. (2001). Nilai melanosis berkisar 0-9. Udang diletakkan di atas nampan dibandingkan dengan udang segar menggunakan 30 orang panelis semi terlatih. Uji melanosis dilakukan pengamatan pada hari ke-0, hari ke-2, hari ke-4, hari ke-6, hari ke-8, dan hari ke-10.

\section{Pengujian organoleptik}

Pengujian organoleptik dilakukan dengan menggunakan scoresheet udang segar sesuai kriteria SNI 01-2728.1-2006 tentang Spesifikasi Udang Segar 1. Udang diletakkan di atas nampan dan diuji oleh 30 panelis semi terlatih (BSN 2006).

\section{Pengujian warna}

Uji warna dilakukan menggunakan alat chromameter, sebelum digunakan untuk mengukur sampel, alat dikalibrasi terlebih dahulu dengan platstandarberwarnaputih. Plat standar ini memiliki nilai $L^{*}=90.45 ; a^{*}=1.32$ dan $b^{*}=-4.15$. Kepala optik ditempelkan ke plat putih, sehingga bagian belakang dari plat menghadap ke sumber sinar. Menu untuk menggunakan skala pengukuran $L^{*}, a^{*}$ dan $b^{*}$ dipilih. Prosedur selanjutnya adalah ditekan tombol start sehingga akan terbaca data yang merupakan rata-rata dari ketiga nilai tersebut. Alat yang telah terkalibrasi menunjukkan 
nilai pembacaan yang sesuai dengan nilai plat standar, yaitu kepala optic ditempelkan pada sampel, kemudian pembacaan akan dimulai ketika tombol start ditekan (Andarwulan et al. 2011).

\section{Analisis Data}

Data yang ditampilkan merupakan nilai rata-rata standar deviasi dari tiga kali pengulangan. Data hasil uji melanosis dan warna dianalisis secara statistik dengan analysis of variance (ANOVA) dengan batas kepercayaan $95 \%(\mathrm{p}<0,05)$, dan menggunakan software Statistical of Package for the Social Science (SPSS) versi 16. Data hasil analisis statistik tersebut, yang memberikan pengaruh berbeda nyata, dilanjutkan dengan uji lanjut Duncan. Data hasil uji organoleptik dianalisis dengan menggunakan statistik non parametik dengan kruskal-wallis dilanjutkan dengan multiple comparisson.

\section{HASIL DAN PEMBAHASAN Hasil Analisis Nilai Melanosis}

Hasil uji ANOVA menunjukkan nilai $\mathrm{p}<0,05$, sehingga terdapat beda nyata pada semua jenis perlakuan mangrove dan sodium metabisulfit terhadap udang vaname selama penyimpanan 10 hari pada suhu $0^{\circ} \mathrm{C}$ berpengaruh signifikan terhadap nilai melanosis. Hasil uji lanjut duncan untuk setiap jenis perlakuan mangrove dan sodium metabisulfit menunjukkan bahwa pada penyimpanan hari ke-0 dan hari ke2 , semua jenis perlakuan mangrove dan sodium metabisulfit terhadap udang tidak berpengaruh nyata terhadap nilai melanosis. Penyimpanan hari ke-4 mulai terjadi perbedaan yang signifikan nilai melanosis udang dengan nilai melanosis udang pada hari ke-0 dan ke-2, kecuali perlakuan perendaman sodium metabisulfit. Kecepatan pembentukan melanosis semakin meningkat setelah hari ke-4. Penyimpanan pada hari ke-10, udang tanpa perlakuan mempunyai nilai melanosis tertinggi yaitu $8,50 \pm 0$. Udang yang direndam menggunakan ekstrak R. apiculata 25\% menunjukkan nilai tertinggi yaitu $8,33 \pm 0,28$ yang tidak berbeda nyata dengan kontrol. Nilai melanosis terendah terdapat pada udang yang direndam sodium metabisulfit (SMS) 1,25\% yaitu $6,50 \pm 0,2$. Nilai melanosis udang yang direndam ekstrak mangrove terendah yaitu udang yang direndam dengan $R$. mucronata $50 \%$ sebesar $7,5 \pm 0,86$. Nilai ini tidak berbeda nyata dengan nilai melanosis udang yang direndam dengan SMS 1,25\%. Semakin tinggi nilai melanosis, maka semakin banyak terbentuk bintik hitam (melanin) pada tubuh udang. Semakin rendah nilai melanosis maka semakin sedikit bintik hitam yang terbentuk pada tubuh udang. Nilai melanosis pada udang dengan berbagai perlakuan yang disimpan selama 10 hari pada suhu $0^{\circ} \mathrm{C}$ disajikan pada Figure 1.

Melanosismerupakan peristiwaterjadinya pembentukan bintik hitam pada tubuh udang yang dimulai pada bagian kepala, karapas, hingga bagian ekor dan kaki udang (Nirmal et al. 2015). Melanosis tetap terjadi walaupun udang disimpan dalam kondisi suhu rendah, oleh karena itu diperlukan upaya-upaya untuk menghambat melanosis seperti menggunakan ekstrak tanaman, bahan tambahan yang aman dan perlakuan pengolahan seperti tekanan, pembekuan dan kemasan vakum (Pan et al. 2019). Penyimpanan hari ke-0 pada suhu $0^{\circ} \mathrm{C}$, udang masih terlihat sangat segar dapat dilihat pada Figure 2. Udang dengan berbagai perlakuan pada penyimpanan hari ke-10 pada suhu $0^{\circ} \mathrm{C}$ disajikan pada Figure 3.

Penyimpanan hari ke-10 menunjukkan kenampakan udang yang telah dipenuhi oleh melanosis, kecuali untuk udang dengan perlakuan perendaman Muc 50\%, Api $50 \%$, dan SMS 1,25\%. Penambahan ekstrak A. marina baik $25 \%$ maupun $50 \%$ tidak menunjukkan penghambatan melanosis pada udang. Penghambatan melanosis udang oleh ekstrak R. mucronata 50\%, R. apiculata 50\% diduga karena terdapat kandungan fitokimia berfungsi sebagai antioksidan yang mencegah atau menonaktifkan enzim PPO pada udang. Penggunaan konsentrasi ekstrak yang lebih tinggi yaitu 50\% dapat menghambat melanosis lebih baik dibandingkan dengan konsentrasi $25 \%$. Ridlo et al. (2017) menjelaskan bahwa semakin besar konsentrasi ekstrak, persentase inhibisi akan semakin tinggi.

Kandungan senyawa dalam ekstrak mangrove yang diduga dapat menghambat pembentukan melanosis pada udang adalah 




Figure 1 Growth chart of melanosis in whiteleg shrimp: R. mucronata $25 \%(\diamond) ;$ R. mucronata $50 \%(-)$ R. apiculata $25 \%(--)$; R. apiculata $50 \%(-)$; A. marina $25 \%(*)$; A. marina $50 \%(-\infty)$; control ( $\rightarrow$ ); sodium metabisulfit 1.25\% (-).

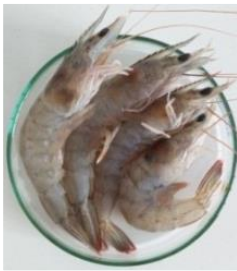

A

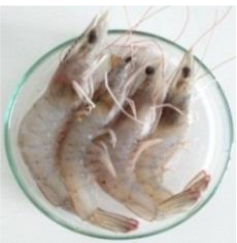

E

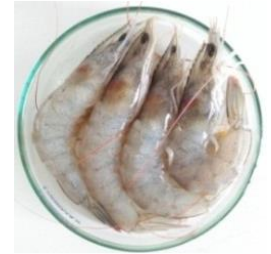

B

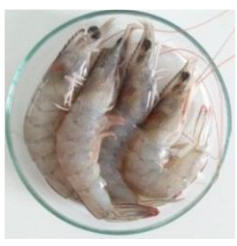

$\mathrm{F}$



C

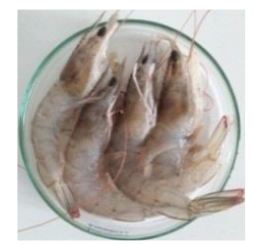

G

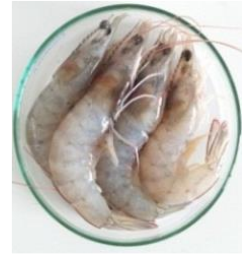

$\mathrm{D}$

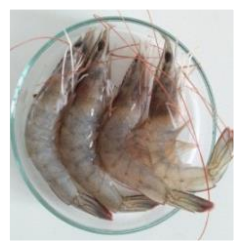

$\mathrm{H}$

Figure 2.Growth rate of whiteleg shrimp on day storage 0: A) $R$. mucronata $25 \%$, B) $R$. mucronata $50 \%$, C) R. apiclata 25\%, D) R. apiculata 50\%, E) A. marina 25\%, F) A. marina 50\%, G) control, H) sodium metabisulfite 1,25\%.

flavonoid, tanin, dan kuinon. Yuan et al. (2015) menunjukkan bahwa pelapisan kitosan dikombinasikan dengan ekstrak teh hijau dapat digunakan sebagai alternatif alami yang efektif untuk sintetis agen antimelanosik untuk menghambat melanosis postmortem dan meningkatkan kualitas udang selama penyimpanan dalam es. Sinergi penghambatan melanosis udang putih oleh ekstrak teh hijau dan kitosan karena efek gabungan dari penghambatan PPO oleh ekstrak daun teh serta antioksidan dan antimikroba, dan aktivitas penghalang oksigen kitosan selama penyimpanan. Kartikasari et al. (2017) menunjukkan bahwa ekstrak batang $X$. granatum dengan pelarut akuades dapat menghambat melanosis udang dan Lapolisa et al. (2011) melaporkan ekstrak X. granatum mengandung flavonoid, saponin, tanin dan fenol.

\section{Hasil Pengujian Organoleptik}

Pengujian organoleptik dilakukan sesuai dengan berdasarkan SNI 01-2346-2006 menggunakan scoresheet dengan parameter uji kenampakan, bau, dan tekstur. Hasil uji organoleptik pada udang yang diberi ekstrak mangrove, disajikan pada Figure 4.

Figure 4 menunjukkan nilai kenampakan udang yang direndam dalam $R$. mucronata $50 \%$ dan $R$. apiculata 50\% mempunyai nilai tertinggi dibandingkan dengan ekstrak 

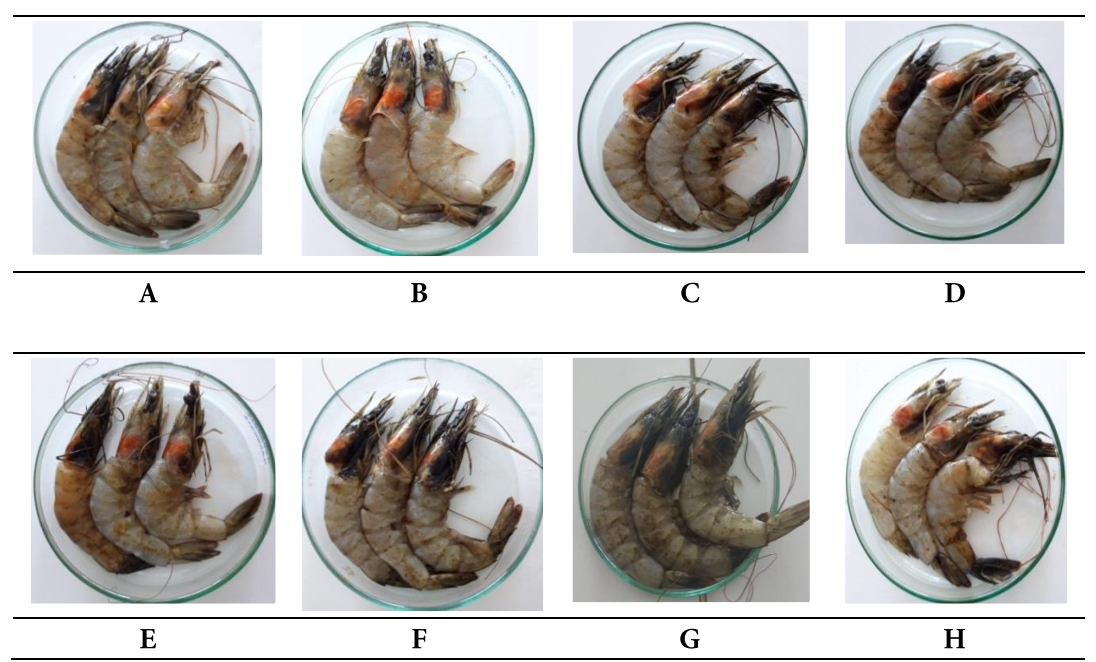

Figure 3 Growth rate of whiteleg shrimp on tenth day storage at $0^{\circ} \mathrm{C}$ : (A) R. mucronata $25 \%$;

(B) R. mucronata 50\%; (C) R. apiculata 25\%; (D) R. apiculata 50\%; (E) A. marina 25\%;

(F) A. marina $50 \%$; $(\mathrm{G})$ control; $(\mathrm{H})$ sodium metabisulfit $1.25 \%$.

mangrove lainnya. Keduanya ekstrak tersebut mempunyai nilai organoleptik yang tidak berbeda nyata dari penyimpanan hari ke- 0 hingga penyimpanan harike-6, namun berbeda nyata dengan ekstrak mangrove lainnya dan kontrol udang tanpa perlakuan. Hari ke-8 dan hari ke-10, nilai atribut kenampakan secara keseluruhan ekstrak mengalami penurunan yang drastis, sedangkan nilai kenampakan udang yang direndam SMS 1,25\% tidak mengami penurunan secara drastis. Hari ke10 nilai atribut kenampakan udang dengan perendaman SMS 1,25\% mempunyai nilai yang paling tinggi dibandingkan dengan keseluruhan ekstrak mangrove. Kontrol udang tanpa perlakuan mempunyai nilai kenampakan terendah. Secara keseluruhan udang dengan perendaman ekstrak mangrove dapat dipertahankan nilai kenampakannya, dengan nilai kenampakan tertinggi adalah perlakuan $R$. mucronata $50 \%$ dan $R$. apiculata $50 \%$, namun tidak lebih tinggi dari nilai kenampakan perlakuan SMS 1,25\%.

Atribut kenampakan udang berhubungan dengan warna udang. Kenampakan udang merupakan salah satu mutu organoleptik kemunduran mutu udang. Kenampakan udang ketika masih segar pada saat pre rigor nampak jernih. Kenampakan ini menjadi berubah ketika fase rogor mortis, warna udang menjadi kekuningan dan mulai terbentuk bintik hitam. Perubahan selanjutnya adalah warna merah muda dan terbentuk banyak bintik hitam pada saat post rigor, dan kenampakan udang selanjutnya menjadi merah dan terbentuk warna hitam yang banyak sekali (Nurhayati et al. 2018)

Seluruh perlakuan jenis ekstrak buah mangrove tidak begitu memengaruhi nilai bau udang. Penambahan esktrak buah mangrove dapat mempertahankan bau udang. Ekstrak mangrove yang menghasilkan bau lainnya walaupun tidak begitu memengaruhi bau asli udang vaname. Bau ini diduga karena adanya kandungan minyak atsiri yang terdapat pada buah mangrove, namun biasanya minyak atsiri ini sengaja ditambahkan pada bahan pangan sesuai dengan fungsinya. Antara dan Wartini (2010) menjelaskan bahwa minyak atsiri atau minyak eteris adalah minyak mudah menguap yang diperoleh dari tanaman dan merupakan campuran dari senyawa-senyawa volatile yang dapat diperoleh dengan destilasi, pengepresan ataupun ekstraksi. Hampir semua tanaman berbau mengandung minyak atsiri, tergantung dari tipe tanaman. Beberapa bagian tanaman dapat digunakan sebagai sumber minyak atsiri seperti buah, biji, bunga, daun, batang, akar, kulit kayu, maupun kayunya.

Tingkat penerimaan panelis terhadap parameter tekstur secara organoleptik pada udang vaname semakin lama semakin menurun. Penambahan keseluruhan ekstrak mangrove dan SMS $1,25 \%$ pada udang menunjukkan hasil yang berbeda nyata dengan kontrol udang tanpa perlakuan. 
(a)

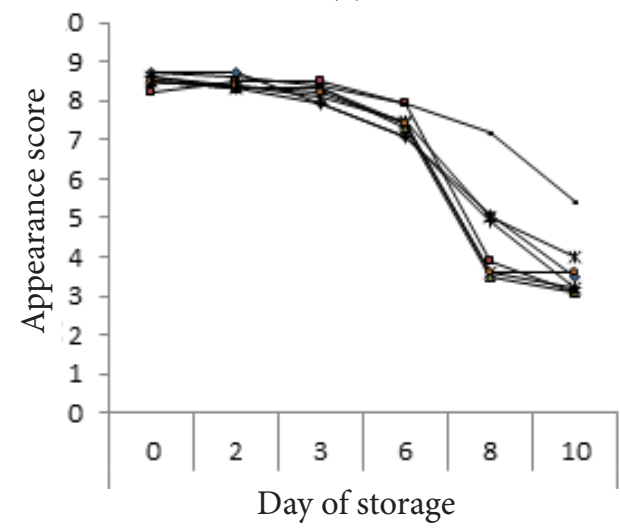

(b)

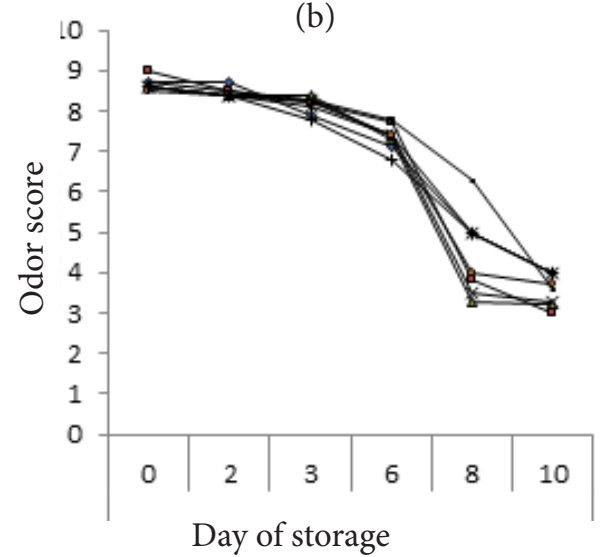

(c)

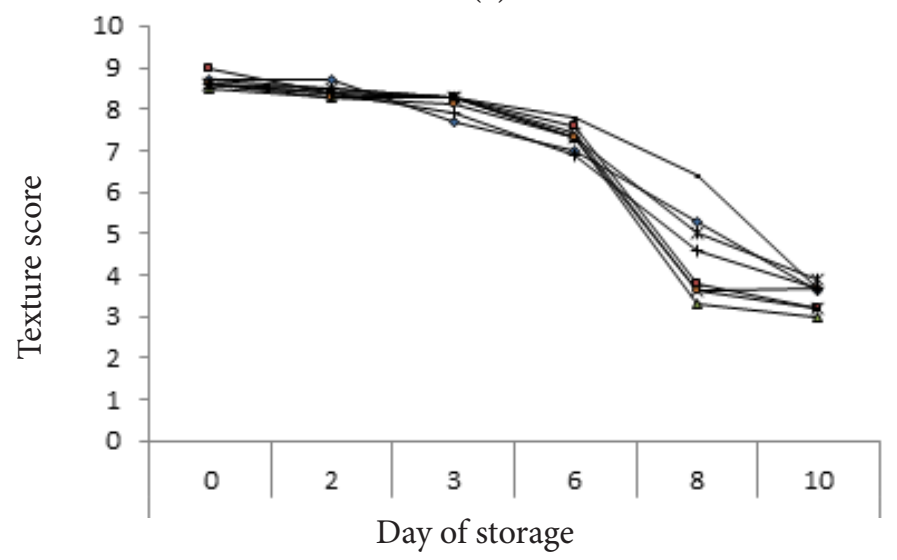

Figure 4 Organoleptic value of whiteleg shrimp (a) appearance; (b) smell; (c) texture; $R$. mucronata 25\%( $\bullet$ ); R. mucronata $50 \%(-\rightarrow)$; R. apiculata $25 \%\left(-\triangle_{-}\right)$; R. apiculata $50 \%(\rightarrow)$; A. marina $25 \%(*)$;

A. marina $50 \%(-\infty)$; control $(\rightarrow)$; sodium metabisulfit $1.25 \%(-)$.

Penambahan mangrove dan SMS 1,25\% dapat mempertahankan tekstur udang vaname. Kemunduran mutu tekstur daging udang berhubungan dengan peristiwa autolisis yaitu pemecahan daging ikan/udang yang disebabkan oleh enzim protease yang banyak terdapat pada kepala udang (Singh dan Benjakul 2018). Komponen fitokimia seperti grup phenolik mempunyai kemampuan menghambat aktivitas enzim protease sebesar $22-56 \%$. Beberapa komponen tersebut antara lain asam galat, tannin, quersetin, rutin, katekin, hesperidin, dan asam sinamik (Razaet al. 2015). Enzim protease juga berperan dalam mengaktifkan pro-PPO menjadi enzim PPO aktif mengakibatkan pembentukan melanosis pada udang (Wang et al. 2006). Vakili dan Ardakani (2018) melaporkan bahwa perlakuan perendaman udang pada ektrak kulit jeruk kemudian udang disimpan selama 12 hari pada suhu $1-4{ }^{\circ} \mathrm{C}$, selain dapat menghambat melanosis, ekstrak juga dapat mempertahankan tekstur udang.

\section{Hasil Pengujian Warna}

Pengujian warna dilakukan dengan mengukur nilai $\mathrm{a}^{*}, \mathrm{~b}^{*}$ dan L. Nilai $\mathrm{a}^{*}$ dan $\mathrm{b}^{*}$ pada perlakuan perendaman udang dalam ekstrak buah mangrove dan SMS 1,25\% menunjukkan nilai $\mathrm{p}>0,05$, tidak berbeda nyata dengan udang tanpa perlakuan sehingga data tidak ditampilkan. Nilai $L^{*}$ pada perlakuan udang perendaman udang dalam ekstrak buah mangrove dan SMS $1,25 \%$ menunjukkan nilai $\mathrm{p}<0,05$, terjadi perbedaan yang nyata dengan kontrol udang tanpa perlakuan. Nilai $L^{*}$ pada udang yang direndam dalam ekstrak mangrove dan SMS 1,25\% disajikan pada Figure 5. 


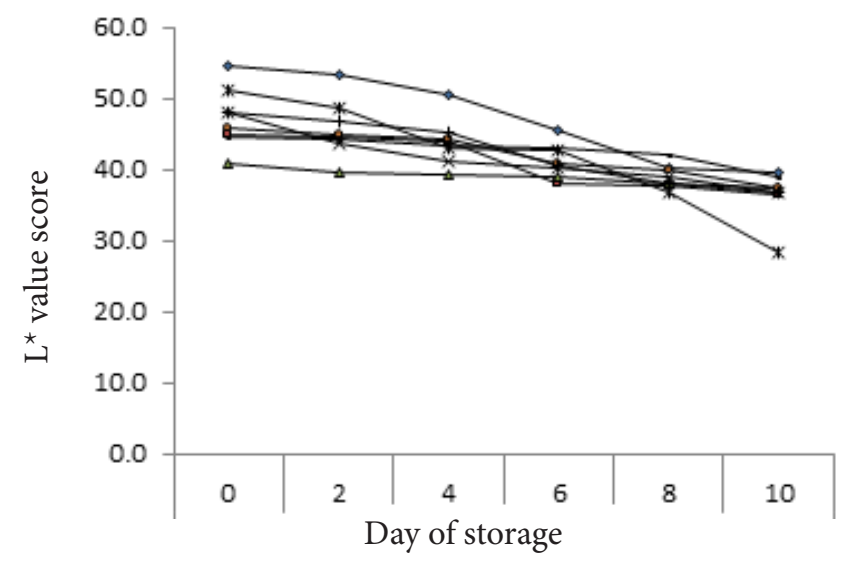

Figure 5 Decrease of $\mathrm{L}^{*}$ color value in whiteleg shrimp R. mucronata 25\% (-); R. mucronata 50\% $(\rightarrow)$ R. apiculata $25 \%\left(-\triangle_{-}\right) ; R$. apiculata $50 \%\left(\star_{-}\right) ;$A. marina $25 \%(*)$; A. marina $50 \%(-\infty)$; control $(\rightarrow)$; sodium metabisulfit $1.25 \%(-)$.

Nilai $\mathrm{L}^{*}$ tertinggi pada hari ke- 0 adalah pada udang yang direndam menggunakan $R$. mucronata $25 \%(54,5)$ dan terendah R. apiculata 25\% $(40,87)$. Perubahan warna $\mathrm{L}^{*}$ pada udang vaname semakin lama penyimpanan udang, maka semakin menurun nilai $\mathrm{L}^{*}$ pada hari ke-2 hingga hari ke-10. Penyimpanan hari ke 10 , nilai $L^{*}$ tertinggi pada udang dengan perlakuan perendaman R. mucronata $25 \%(39,51)$ dan tidak berbeda nyata dengan nilai $L^{*}$ pada perlakuan R. mucronata $50 \%(36,38)$, R. apiculata $50 \%$ $(36,65)$ dan sodium metabisulfit $(38,87)$. Nilai $\mathrm{L}^{*}$ terendah pada perlakuan A. marina $25 \%$ $(28,42)$. Nilai $L^{*}$ yang diukur menggunakan alat chromameter tersebut mendukung data nilai melanosis dan kenampakan udang yang diukur secara sensori. Perlakuan perendaman ekstrak buah mangrove pada udang yang terbaik secara sensori adalah perlakuan menggunakan ekstrak buah mangrove R. mucronata $50 \%$ dan R. apiculata $50 \%$, dan perlakuan terbaik menggunakan alat adalah perendaman $R$. mucronata $25 \%$ namun tidak berbeda nyata dengan $R$. apiculata $50 \%$. Bland et al. (2018) melaporkan bahwa pengukuran menggunakan sensori berupa indera manusia terkadang perlu divalidasi menggunakan alat untuk memastikan ketepatan perbedaan pengukuran suatu produk. Warna $\mathrm{L}^{*}$ pada udang dengan perlakuan SMS $1,25 \%$, lebih normal dan tidak mengalami penurunan secara drastis. Perlakuan perendaman menggunakan ekstrak buah A. marina $25 \%$ mempunyai nilai $L^{*}$ yang paling rendah.

Nilai $L^{\star}$ menunjukkan tingkat kecerahan. Warna benda yang dicirikan oleh nilai $\mathrm{L}^{*}$ berarti cenderung memiliki warna akrobatik putih, abu-abu dan hitam. Nilai $a^{*}$ menyatakan warna cenderung merah dan nilai $b^{*}$ menyatakan warna cenderung kuning (Purwani 2006). Yam dan Papadakis (2004) menjelaskan bahwa warna $L^{*}, a^{*}, b^{*}$ memberikan pandangan serta makna dari setiap dimensi yang dibentuk, yaitu besaran $\mathrm{L}^{*}$ untuk mendeskripsikan kecerahan warna (nilai $0-100$ ), semakin kecil nilai $L^{*}$ menunjukkan tingkat kecerahan semakin menurun (semakin gelap), dan semakin besar nilai $L^{*}$ maka semakin cerah sampel yang dianalisis. Dimensi a ${ }^{*}$ mendeskripsikan jenis warna hijau-merah (nilai -120 - 120). Dimensi $b^{*}$ untuk jenis warna biru-kuning $(-120-120)$. Model warna $L^{*}, a^{*}, b^{*}$ sering digunakan dalam studi penelitian makanan.

Yatmaz dan Gogoklu (2016) melaporkan bahwa sodium metabisulfit dan kombinasinya lebih efektif daripada ekstrak tanaman untuk mempertahankan cahaya, kemungkinan karena beberapa sifat sulfit pada SMS, yaitu sebagai agen pereduksi efektif yang memiliki sifat pemutihan.

\section{KESIMPULAN}

Ekstrak buah mangrove R. mucronata 50\% dan $R$. apiculata $50 \%$ dapat memperlambat pembentukan melanosis pada udang vaname yang disimpan selama 10 hari pada suhu $0^{\circ} \mathrm{C}$. Nilai organoleptik udang dengan perlakuan 
ekstrak tersebut dapat mempertahankan parameter kenampakan tanpa mempengaruhi bau dan tekstur udang. Ekstrak A. marina 25\% memiliki tingkat keefektifan terendah dalam mempertahankan nilai $\mathrm{L}^{*}$ warna pada udang vaname.

\section{UCAPAN TERIMA KASIH}

Penelitian ini dibiayai oleh Unit Penelitian dan Pengabdian Masyarakat (UPPM) Jurusan Penyuluhan Perikanan, Sekolah Tinggi Perikanan.

\section{DAFTAR PUSTAKA}

Abdullah. 2011. Potensi bakau Rhizophora apiculata sebagai inhibitor tirosinase dan antioksidan. [Skripsi] Bogor (ID): Institut Pertanian Bogor.

A'in C, Suryanti, Sulardiono B. 2017. Kandungan gizi pada produk olahan mangrove (Krumang, Bomang, Simang) produksi Kelompok Tani Ngudi Makaryo. Jurnal Info. 19(1): 16-33.

Andarwulan N, Kusnandar F, Herawati D. 2011. Analisis Pangan. Jakarta (ID): Dian Rakyat.

Ashari U, Sahara, Hartoyo S. 2016. Daya saing udang segar dan udang beku Indonesia. Jurnal Manajemen dan Agribisnis. 13(1): $1-13$.

Bland JM, Bett-garber KL, Li CH, Brashear SS, Lea JM, Bechtel PJ. 2018. Comparison of sensory and instrumental methods for the analysis of texture of cooked individually quick frozen and frozen catfish fillets. Food Science \& Nutritioin. 6(6): 16921705.

[BSN] Badan Standardisasi Nasional. 2006. SNI 01-2728.1-2006 Spesifikasi Udang Segar. Jakarta(ID): Badan Standardisasi Nasional.

Cui H, Duan F, Jia S, Cheng F, Yuan K. 2018. Antioxidant and tyrosinase inhibitory activities of seed oils from torreya grandis Fort. ex Lindl. BioMed Research International. (5): 1-10.

Fang X, Sun H, Huang B, Yuan G. 2013. Effect of pomegrenate peel extract on the melanosis of pacific white shrimp (Litopenaeus vannamei) during iced storage. Journal of Food Agriculture and
Environment. 11(1): 105-109.

Giménez, B., Martínez-alvarez Óscar Montero, P., Guillen, M. del C.G., 2010. Characterization of phenoloxidase activity of carapace and viscera from cephalothorax of Norway lobster (Nephrops norvegicus). Food Science and Technology. 43(1): 1240-1245.

Handayani S. 2013. Kandungan flavonoid kulit batang dan daun pohon api-api (Avicennia marina (Forks.) Vierh. sebagai senyawa aktif antioksidan. [Skripsi]. Bogor (ID) : Institut Pertanian Bogor.

Hardoko, Suprayitno E, Puspitasari YE, Amalia R. 2015. Study of ripe Rhizophora mucronata fruit flour as functional food for antidiabetic. International Food Research Journal. 22(3): 953-959.

Imran A, Chawalit J, Somrote K. 2013. Characterization of quality degradation during chilled shrimp (Litopenaeus vannamei) supply chain. International Food Research Journal. 20(4): 1833-1842.

Kartikasari L, Nurhayati APD, Setiawan E, Hidayati D, Ashuri NM, Saadah NN, Muzaki FK, Desmawati I. 2017. Bioaktivitas ekstrak batang Xylocarpus granatum sebagai anti black spot alternatif pada Litopenaeus vannamei pascapanen. Journal of Tropical Biodiversity and Biotechnology. 2(1):16-20.

Montero PA. Avalos, and Perez M. 2001. Characterization of polyphenoloxidase of prawns (Penaeus japonicus). Alternatives to inhibition: additives and high-pressure treatment. Food Chemistry. 75(3): 317324.

Morrissey MT, Sylvia G. 2004. Intrinsic and extrinsic factors affecting efficient utilization of marine resources. Developments in Food Science. 42:37-43.

Nirmal, Benjakul S, Ahmad M, Arfat YA, Panichayupakaranant P. 2015. Undesirable enzymatic browning in crustaceans : causative effects and its inhibition by phenolic chompoundd. Journal of Food Science Nutritions. 55(14): 1992-2003.

Nurhayati T, Kustiariyah, Jacoeb AM, Utari SA, Azizah LH, Hidayat T. 2018. Quality assessment of vannamei shrimp from 
Indonesian waters. Proceedings of the Pakistan Academy of Sciences: B. Life and Environmental Sciences. 55(1): 21-28.

Pan C, Chen S, Hao S, Yang X. 2019. Effect of low-temperature preservation on quality changes in Pacific white shrimp, Litopenaeus vannamei : a review. Journal of Science Food Agriculture. 99(14): 61216128.

Rahimabadi Z, Zarrin K, Zarei M, Gaffari M, Rahnama M. 2016. Effects of genistein on melanosis and microbial quality of Litopenaeus vannamei during ice storage. Iranian Journal of Fisheries Sciences. 15(1): 436-445.

Raza MA, Shahwar, D, Khan T. 2015. Radical Scavenging, Proteases Activities, and Phenolics Composition of Bark Extracts from 21 Medicinal Plants. Ritieni A, editor. [editorial]. Journal of Chemistry. 1-8.

Ridlo A, Pramesti R, Koesoemadji, Supriyantini E, Soenardjo N, 2017. Aktivitas antioksidan ekstrak daun mangrove Rizhopora mucronata. Buletin Oseanografi Marina. 6(2):110-116.

Senapati SR, Kumar GP, Singh CB, Xavier KAM, Chouksey M, Nayak BB. Balange AK. 2017. Melanosis and quality attributes of chill stored farm raised whiteleg shrimp (Litopenaeus vannamei). Journal of Applied and Natural Science. 9(1): 626-631.

Singh A, Benjakul S. 2018. Proteolysis and Its Control Using Protease Inhibitors in Fish and Fish Products : A Review. Food Science and Food Safety. 17(2): 496-509.
Vakili S, Ardakani SAY. 2018. Antioxidant Effect of Orange Peel Extract on Chemical Quality, Sensory Properties, and Black Spots of Farmed White Shrimp. Journal of Nutrition and Food Security. 3(1): 19-26.

Wang Y, Chang P, Chen, H. 2006. Tissue distribution of prophenoloxidase transcript in the Pacific white shrimp Litopenaeus vannamei. Fish and Shellfish Immunology. 20(3): 414-418.

Yam KL, Papakdakis SE. 2004. A simple digital imaging method for measuring and analyzing colour of food surfaces. Journal of Food Engineering. 61(1):137-142.

Yatmaz AH, Gogoklu N. 2016. Effects of plants extract sulphide combinations on melanosis inhibition and quality in shrimp (Aristeus antennatus). International Journal on Food Properties. 19(2):359-370.

Yuan G, Zhang X, Tang W, Sun H. 2015. Effect of chitosan coating combined with green tea extract on the melanosis dan quality of pasific white shrimp during storage in ice. CYTA-Journal of Food. 14(1): 35-40.

Yuniarti T, Sukarno, Yuliana ND, Budijanto S. 2018. Inhibition of enzymatic browning by onion (Allium cepa L.): Investigation on inhibitory mechanism and identification of active compounds. Current Research in Nutrition and Food Science. 6(3): 770780 .

Zolghadri S, Bahrami A, Tareq M, Khan H, Munoz-munoz J, Garcia-molina F. 2019. A comprehensive review on tyrosinase inhibitors. Journal of Enzyme Inhibition and Medicinal Chemistry. 34(1): 279-309. 